\title{
Endocrine and metabolic status of commercial dairy goats during the transition period
}

\author{
F. Zamuner, ${ }^{1 *} \odot$ K. DiGiacomo, ${ }^{1} \oplus$ A. W. N. Cameron, ${ }^{2}$ and B. J. Leury ${ }^{1} \odot$ \\ ${ }^{1}$ Faculty of Veterinary and Agricultural Sciences, University of Melbourne, Parkville, Victoria 3010, Australia \\ ${ }^{2}$ Meredith Dairy Pty Ltd., 106 Cameron Rd, Meredith, Victoria 3333, Australia
}

\begin{abstract}
The aim of this study was to evaluate temporal variations in circulating levels of selected hormones and metabolites in commercial dairy goats during the transition period. Blood samples from 940 goats were collected weekly, from -3 to 3 wk relative to delivery, to measure the effects of level of milk production, parity number, and litter size on concentrations of glucose, $\beta$-hydroxybutyrate (BHB), fatty acids, and plasma urea nitrogen (PUN). A subset of 80 goats [40 low-yielding $(\mathrm{LY},<1.8 \mathrm{~L} / \mathrm{d})$ and 40 high-yielding goats $(\mathrm{HY},>$ $3.7 \mathrm{~L} / \mathrm{d})$ ] were selected from the study population to measure the effects of level of milk production on plasma concentration of insulin, prolactin, and growth hormone. Average $( \pm \mathrm{SD})$ milk yield (from 3 to $30 \mathrm{~d}$ in milk), body weight, and body condition score for the study population were $2.4 \pm 0.78 \mathrm{~L} / \mathrm{d}, 70 \pm 16.0$ $\mathrm{kg}$, and $2.5 \pm 0.28$ units, respectively. Milk yield was moderately correlated with parity number $(\mathrm{r}=0.49)$ but had weak correlation with litter size $(\mathrm{r}=0.14)$. In multiparous but not in primiparous goats, antepartum concentrations of fatty acids and BHB increased with increasing litter size. Concentrations of fatty acids, $\mathrm{BHB}$, and PUN were consistently lower in primiparous goats compared with those in second or greater parity. Postpartum, HY goats had higher ratios of glucose, fatty acids, and BHB to insulin than did LY goats, which might explain the greater mobilization of body tissues and enhanced milk production observed in this group. Collectively, our results indicate that increased milk yield has the most significant influence on the magnitude of body tissue mobilization. Our results also show that goats of higher parity display higher levels of lipid mobilization, and that both pregnancy and lactation are less able to elicit lipomobilization in primiparous compared with multiparous goats.
\end{abstract}

Received December 11, 2019.

Accepted January 28, 2020.

*Corresponding author: fzamuner@student.unimelb.edu.au
Key words: milk yield, parity, litter size, peripartum

\section{INTRODUCTION}

The Australian dairy goat industry has experienced unprecedented growth in recent years. Stimulated by increasing demand for healthy and niche dairy goat products, national goat milk production has more than doubled, from 8 million liters in 2012 to 16.9 million liters in 2016, and the enterprise structure is rapidly moving from small family-owned businesses to largescale production and intensive husbandry systems (Zalcman and Cowled, 2018). However, adoption of intensive production systems and genetic selection for increased milk yield are likely to increase the incidence of peripartum disorders as a consequence of intensified metabolic burden in high-yielding goats (Celi et al., 2008).

The risk of metabolic and infectious diseases is particularly high during the transition period ( $3 \mathrm{wk}$ before to 3 wk after parturition) because around this time a substantial increase in energy requirements to support pregnancy and lactation coincides with a period of depressed feed intake, often resulting in maternal negative energy balance (NEB; Sundrum, 2015; Matthews, 2016). Research in dairy cows has shown that the greater the duration and severity of NEB, the higher the risk of disease development and milk loss (Overton et al., 2017). Similarly, in dairy goats, multiple pregnancies and high milk yield are considered predisposing factors for several metabolic diseases, because both potentially exacerbate NEB (Albay et al., 2014; Radin et al., 2015). Given the high prolificacy and improved milk production of modern dairy goats, commercial goats might be at risk of developing metabolic complications, both ante- and postpartum (Stelletta et al., 2008; Matthews, 2016).

Dairy ruminants cope with NEB through an intricate mechanism of hormonal and metabolic adaptations that regulate interactions among nutrients and nutrient-using organs and tissues (Herdt, 2000). The success or failure of such adaptations will determine 
animal performance in the ensuing lactation (Stelletta et al., 2008; Matthews, 2016). Therefore, correct understanding and characterization of both endocrine and metabolic changes during the transition period are of utmost importance for accurate prediction and prevention of NEB-related metabolic disorders (Matthews, 2016; Overton et al., 2017).

The metabolic health of transitioning dairy cows has been the subject of numerous reviews (Sundrum, 2015; Overton et al., 2017; Wankhade et al., 2017). However, only limited information is available on transitioning dairy goats. Relatively few studies have examined periparturient metabolic changes in dairy goats with respect to parity (Magistrelli and Rosi, 2014; Radin et al., 2015) and litter size (Castagnino et al., 2015; Cappai et al., 2019), and these have had limited numbers of animals in each group ( $\mathrm{n}=4$ to 22$)$. Moreover, to the best of our knowledge, no studies have described changes in hormonal and metabolic profiles of transition dairy goats raised on large-scale commercial farms.

Thus, the aims of this study were (1) to evaluate temporal variations in circulating levels of selected hormones and metabolites involved in the regulation of energy metabolism during the transition period and (2) to investigate the effects of level of milk production, parity number, and litter size on the metabolic profile of periparturient dairy goats from a commercial herd in Australia.

\section{MATERIALS AND METHODS}

All experimental procedures were approved by the Faculty of Veterinary and Agricultural Sciences Animal Ethics and Welfare Committee of the University of Melbourne, Australia (No. 1613846.1).

\section{Animals and Management}

This experiment was conducted at Meredith Dairy commercial farm (Meredith, Australia, 37 $50^{\prime} \mathrm{S}$, $\left.144^{\circ} 04^{\prime} \mathrm{E}\right)$. The farm follows a reproductive calendar based on 4 kidding seasons per year, aiming for 600 does kidding in each of the 4 kidding periods: March, June, September, and November. In total, 1,000 Saanen goats ( $\sim 250$ different goats per season) were selected from the herd over 4 consecutive kidding seasons (June 2016 to March 2017) to be monitored in this study. Further details on animals, management, and measurements of milk yield and milk composition are available in Zamuner et al. (2020). In brief, approximately 1 mo before kidding, primiparous and multiparous goats were brought together and moved to the kidding shed, and began to be fed the fresh-goat TMR. Enrolled goats were kept with their contemporary group ( $\sim 600$ goats) in a collective pen. Goats were fed a TMR ad libitum once daily at around $0700 \mathrm{~h}$; nutrient composition of the diet (per $\mathrm{kg}$ of $\mathrm{DM}$ ) was $28 \% \mathrm{NDF}, 16 \% \mathrm{CP}, 10$ MJ of ME, $18 \mathrm{~g}$ of $\mathrm{Ca}$, and $9 \mathrm{~g}$ of P. Milk composition was measured at wk 6 , and goat $\mathrm{BW}$ and $\mathrm{BCS}$ were measured at wk $-6,0$, and 6 relative to delivery (always before feeding and after the morning milking). The BCS was scored by the same person, adopting a 6-point scale method (Villaquiran et al., 2004).

\section{Blood Sampling: All Does}

Blood samples were collected from all does on the same day $(\sim 250$ each kidding season), starting at around $1100 \mathrm{~h}$, always after the morning milking. Feed was withheld until after blood collection. Goats were sampled in random order, and the interval between the first and last animals sampled was $166 \pm 30$ min (mean $\pm \mathrm{SD}$ ). Blood samples were taken at weekly intervals from wk -3 to 3 relative to the expected kidding date. The actual day of sampling (relative to delivery) was determined by subtracting the date of kidding from the date of sampling, and data were segmented into intervals of $1 \mathrm{wk}$ (i.e., $-21 \pm 3 \mathrm{~d}=\mathrm{wk}-3,-14 \pm 3 \mathrm{~d}$ $=\mathrm{wk}-2$, and so forth). Blood was collected via jugular venipuncture using vacuum tubes $(10 \mathrm{~mL})$ coated with lithium-heparin (BD Vacutainer, Plymouth, UK). Blood samples were immediately placed on ice and centrifuged $\left(1,250 \times g, 4^{\circ} \mathrm{C}\right)$ for 12 min within 1 to 3 $\mathrm{h}$ after collection. Isolated plasma was stored at $-20^{\circ} \mathrm{C}$ until analysis.

\section{Blood Sampling: Subset Group (High vs. Low Milk Yield)}

After the end of the last kidding season (Mar. 2017), a total of 80 goats in second or third lactation were selected (retrospectively) from the study population based on their average milk yield from 3 to 30 DIM. The 10 highest and 10 lowest-yielding goats of each month of kidding were selected for analysis of plasma insulin, prolactin, and growth hormone $(\mathbf{G H})$ concentrations at wk $-3,-1,1$, and 3 , relative to delivery.

\section{Metabolite Analysis: All Does}

Whole-blood concentration of BHB was measured using a hand-held meter (FreeStyle Optium Precision Neo, Abbott Diabetes Care Ltd., Oxfordshire, UK) before plasma separation. Plasma fatty acid, glucose, and urea concentrations were determined spectrophotometrically using commercial kits [respectively, NEFA-C 
ACS-ACOD method, Wako Pure Chemical Industries, Ltd., Osaka, Japan (modified as per the methods of Johnson and Peters (1993); Infinity Glucose Oxidase Liquid, Thermo Fisher Scientific, Waltham, MA; and Infinity Urea Liquid Stable Reagent, Thermo Fisher Scientific]. The inter- and intra-assay coefficients of variation $(\mathrm{CV})$ were $<6.0$ and $<3.4 \%$ for glucose, $<8.5$ and $<3.5 \%$ for fatty acid concentration, and $<6.3$ and $<3.4 \%$ for plasma urea nitrogen (PUN).

\section{Hormone Analysis: Subset Groups (High vs. Low Milk Yield)}

Plasma prolactin and GH concentrations were measured in duplicate using the method described by Thomas et al. (1990). The sensitivity of the assay was $0.2 \mathrm{ng} / \mathrm{mL}$ for prolactin and $0.3 \mathrm{ng} / \mathrm{mL}$ for $\mathrm{GH}$. The intra-assay CV were $<10 \%$ between 0.8 and $27.3 \mathrm{ng} /$ $\mathrm{mL}$ for prolactin and $<10 \%$ between 1.2 and $51.9 \mathrm{ng} /$ $\mathrm{mL}$ for GH. Plasma insulin concentration was measured in duplicate using RIA kits (Porcine Insulin Cat. \# PI-12K, Millipore Corporation, Billerica, MA). The assay sensitivity range was 0.4 to $0.7 \mu \mathrm{U} / \mathrm{mL}$, the intraassay $\mathrm{CV}$ was $<10 \%$ between 1.5 and $212.1 \mu \mathrm{U} / \mathrm{mL}$, and inter-assay $\mathrm{CV}$ was $5.3 \%$ at $16.0 \mu \mathrm{U} / \mathrm{mL}$ [quality control (QC) 1] and $5.9 \%$ at $49.5 \mu \mathrm{U} / \mathrm{mL}$ (QC2).

\section{Calculations and Statistical Analyses}

To account for confounding effects of labor-induced changes in the concentrations of hormones and metabolites, antepartum calculations included observations from $\mathrm{d}-24$ to -3 , and postpartum calculations included observations from d 3 to 24 relative to delivery. The level of milk production was determined, retrospectively, based on the average milk yield (L/d) from 3 to 30 DIM. The ratios of glucose, fatty acids, and BHB to insulin were calculated as 1 unit of glucose, fatty acids, or BHB (mmol/L) per 1 unit of insulin $(\mu \mathrm{U} / \mathrm{mL})$.

Due to the potential effects of animal handling on milk production, individual milk produced the day before blood sampling (Milk-S) was used to calculate associations between simultaneous observations of blood parameters and milk yield. Primiparous goats produced approximately $40 \%$ less milk (3 to 30 DIM) than did multiparous goats. To avoid bias due to this considerably lower milk yield, only data from multiparous goats were used to calculate (1) the effects of the level of milk production on metabolite concentrations and (2) the effects of elevated fatty acids and BHB on Milk-S.

For the purposes of data analysis, the following intervals were used as cut points for BHB concentrations: $<0.8,0.8$ to 1.6 , and $>1.6 \mathrm{mmol} / \mathrm{L}$ (Albay et al., 2014;
Marutsova and Binev, 2017; Caré et al., 2018). The cut point for elevated fatty acids in postpartum dairy cows ( $\geq 0.7 \mathrm{mmol} / \mathrm{L}$; Overton et al., 2017) was adapted to the following intervals: $<0.8,0.8$ to 1.6 , and $>1.6$ $\mathrm{mmol} / \mathrm{L}$. Blood samples were dichotomized into 4 yes or no groups, according to fatty acid and BHB intervals. The total numbers of positive events $(0,1,2$, or 3 times) antepartum (d -24 to -1 ) and postpartum (d 0 to 24) were calculated for each goat separately. The percentage of goats with at least 1 positive event above the cut point was calculated as the number of positive events $\div$ number of goats tested $\times 100$. Goats were dichotomized based on the dry-off date $(\leq 30$ DIM $=$ yes or no).

Data were categorized into week of blood sampling $(-3,-2,-1,0,1,2$, and 3$)$, period (ante- and postpartum), month of kidding (Mar., Jun., Sep., and Nov.), parity number $(1,2,3$, and $4+$ ), litter size (LS: 1,2 , and 3 fetuses), and level of milk production [low yield $(\mathbf{L Y}),<2.4 \mathrm{~L} / \mathrm{d}$; medium yield (MY), 2.4 to $3.1 \mathrm{~L} / \mathrm{d}$; and high yield $(\mathbf{H Y}),>3.1 \mathrm{~L} / \mathrm{d}]$. Statistical analyses were performed using Minitab software (version 18.1; Minitab Inc., State College, PA). All outcome variables were screened for normality by calculation of kurtosis and skewness and by visual assessment of standardized residuals distribution. Data from repeated measurements were analyzed using the Mixed Effects Model (restricted maximum likelihood, 2-sided 95\% CI), and data from non-repeated-measurements were analyzed using the General Linear Model (2-sided 95\% CI) of Minitab. For all models, the random effect of goat was nested with month of kidding to account for variations between month of kidding. The effects of parity number, LS, BW, BCS, and time of blood sampling, as well as suspected 2-way interactions, were tested in all models and retained when significant $(P<0.05)$. The Bonferroni method with $95 \%$ CI was used for pairwise comparisons. The Spearman rho correlation was used to examine relationships between variables of interest (using simultaneous observations for each goat at each sampling event). Binary logistic regression was used to evaluate associations between the number of events at or above fatty acid and BHB cut points (continuous variable) and removal from the milking herd $\leq 30$ DIM (binary response).

\section{Study Population}

Values for glucose, fatty acids, BHB, PUN, and fatty acid-to-BHB ratio were log-transformed to achieve normality. The interaction week of blood sampling $x$ parity number $\times$ LS was not significant, but preliminary analysis showed significant differences between 
primiparous and multiparous goats of equal LS. Hence, the effects LS on ante- and postpartum concentrations of metabolites were analyzed in primiparous and multiparous goats separately. Multiparous goats were grouped according to BHB and fatty acid concentration range $(<0.8,0.8$ to 1.6 , and $>1.6 \mathrm{mmol} / \mathrm{L})$ for estimation of Milk-S in each group.

\section{High- Versus Low-Yield Subset Groups}

Values for fatty acids, BHB, insulin, GH, prolactin, and ratios of glucose, fatty acids, and BHB to insulin were log-transformed to achieve normality. Values for ratios of glucose, fatty acids, and BHB to insulin were analyzed for wk 1 and 3 separately.

\section{Data Presentation}

Results for log-transformed variables were reported after back-transformation. Data are presented as means \pm SE unless otherwise stated.

\section{RESULTS}

Out of 1,000 animals, 60 were excluded from the experiment due to abortions, death, or kidding delays. Thus, 940 does were included in the final analysis. The final number of enrolled does is listed in Table 1. The percentages of goats delivering 1,2 , or 3 kids were 35 , 55 , and $10 \%$, respectively, and the average litter size was 1.75 kids per goat.

Production data according to level of milk production, parity number, and litter size are reported in Table 2. The mean $( \pm \mathrm{SD})$ milk yield, BW, and BCS for the study population were, respectively, $2.4 \pm 0.78$ $\mathrm{L} / \mathrm{d}, 70 \pm 16.0 \mathrm{~kg}$, and $2.5 \pm 0.28$ units. Milk yield was moderately correlated with $\mathrm{BW}(\mathrm{r}=0.52 ; P<0.001)$ but not with BCS ( $\mathrm{r}=0.01 ; P=0.919)$. Litter size was weakly correlated with BCS $(\mathrm{r}=-0.25 ; P<0.001)$.

\section{Metabolite Concentrations During the Transition Period}

For all metabolites we discovered a significant $(P$ $<0.001$ ) difference between ante- and postpartum concentrations [glucose: 3.3 vs. 3.1, standard error of differences $(\mathbf{S E D})=0.02$; fatty acids: 0.42 vs. 0.81, $\mathrm{SED}=0.016$; BHB: 0.24 vs. $0.43, \mathrm{SED}=0.011$; and PUN: 6.9 vs. $8.4, \mathrm{SED}=0.08$, ante- vs. postpartum, respectively]. Weekly variations in plasma concentration of glucose, fatty acids, BHB, and PUN are reported in Table 3. Concentrations of glucose, BHB, and PUN were relatively constant until wk -1 , sharply increasing (except for PUN) at wk 0, the week of parturition.

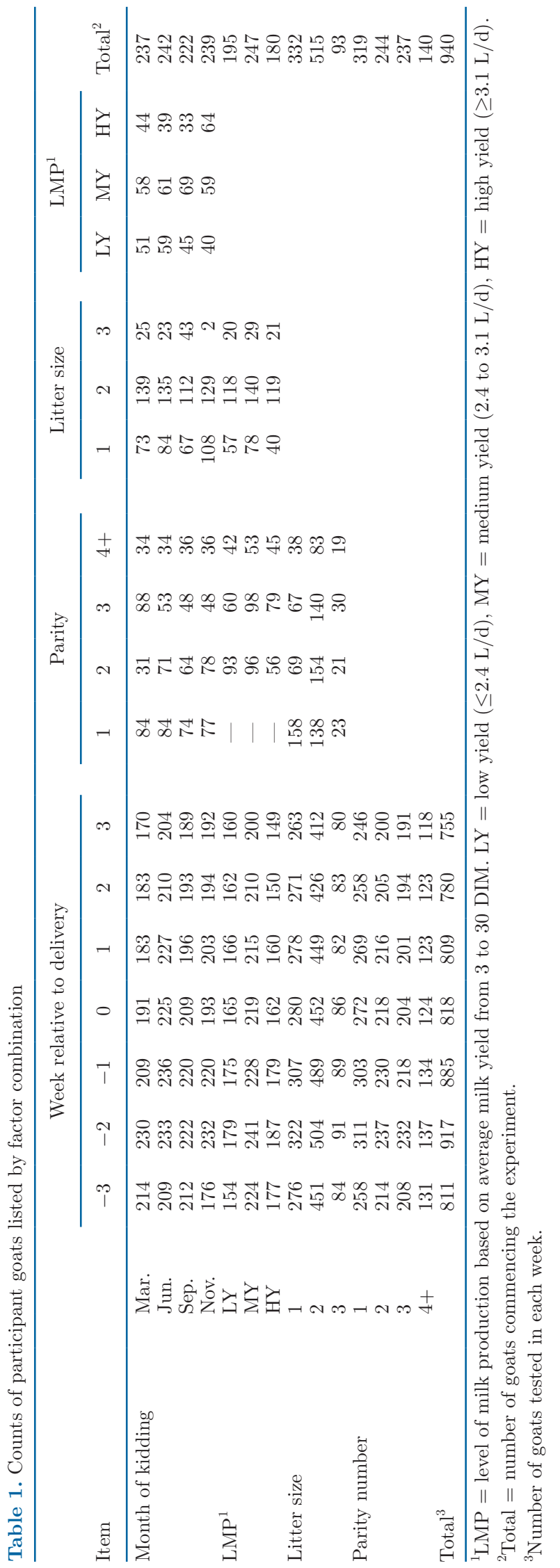


Table 2. Effect of level of milk production (LMP), parity number $(\mathrm{PN})$, and litter size $(\mathrm{LS})$ on mean $\mathrm{BW}(\mathrm{kg}), \mathrm{BCS}$, and average daily milk yield $(\mathrm{L} / \mathrm{d})$ of commercial dairy goats during the first month of lactation $(\mathrm{n}=940)^{1}$

\begin{tabular}{lccc}
\hline Item & $\mathrm{BW}^{2}$ & $\mathrm{BCS}^{2}$ & Milk $^{3}$ \\
\hline LMP $^{4}$ & $76^{\mathrm{B}}$ & $2.5^{\mathrm{A}}$ & $2.0^{\mathrm{C}}$ \\
LY & $78^{\mathrm{B}}$ & $2.5^{\mathrm{AB}}$ & $2.7^{\mathrm{B}}$ \\
MY & $80^{\mathrm{A}}$ & $2.4^{\mathrm{B}}$ & $3.5^{\mathrm{A}}$ \\
HY & 1.0 & 0.03 & 0.03 \\
SED & 0.049 & 0.043 & $<0.001$ \\
$P$-value & & & \\
PN & $54^{\mathrm{D}}$ & $2.4^{\mathrm{B}}$ & $1.9^{\mathrm{C}}$ \\
1 & $72^{\mathrm{C}}$ & $2.5^{\mathrm{A}}$ & $2.6^{\mathrm{B}}$ \\
2 & $76^{\mathrm{B}}$ & $2.4^{\mathrm{B}}$ & $2.8^{\mathrm{A}}$ \\
3 & $82^{\mathrm{A}}$ & $2.5^{\mathrm{AB}}$ & $2.7^{\mathrm{AB}}$ \\
$4+$ & 1.1 & 0.03 & 0.06 \\
SED & $<0.001$ & $<0.001$ & $<0.001$ \\
$P$-value & & & \\
LS & $72^{\mathrm{A}}$ & $2.6^{\mathrm{A}}$ & $2.4^{\mathrm{B}}$ \\
1 & $70^{\mathrm{B}}$ & $2.4^{\mathrm{B}}$ & $2.5^{\mathrm{A}}$ \\
2 & $70^{\mathrm{AB}}$ & $2.4^{\mathrm{B}}$ & $2.6^{\mathrm{A}}$ \\
3 & 1.1 & 0.03 & 0.07 \\
SED & 0.035 & $<0.001$ & 0.002 \\
$P$-value & & & \\
\hline
\end{tabular}

$\overline{{ }^{\mathrm{A}-\mathrm{C}} \text { Means within a column with different uppercase superscripts differ }}$ $(P<0.05)$

${ }^{1}$ Number of does by factor combination is presented in Table 1.

${ }^{2}$ Measured within 1 wk relative to parturition.

${ }^{3}$ Average milk yield (L/d) from 3 to 30 DIM.

${ }^{4}$ Based on average milk yield from 3 to 30 DIM (excluding data for primiparous goats). $\mathrm{LY}=$ low yield $(\leq 2.4 \mathrm{~L} / \mathrm{d}), \mathrm{MY}=$ medium yield $(2.4$ to $3.1 \mathrm{~L} / \mathrm{d}), \mathrm{HY}=$ high yield $(\geq 3.1 \mathrm{~L} / \mathrm{d}), \mathrm{SED}=$ standard error of differences.

Plasma glucose reached a peak of $3.6 \mathrm{mmol} / \mathrm{L}$ at wk 0 , rapidly decreasing after birth. Plasma fatty acid concentrations increased continuously $(P<0.001)$ from wh -1 to its highest concentration $(0.89 \mathrm{mmol} / \mathrm{L})$ at wk 3, and BHB concentration rose sharply from wk -1 to a peak of $0.44 \mathrm{mmol} / \mathrm{L}$ at wk 1 and remained above $0.4 \mathrm{mmol} / \mathrm{L}$ until the end of the study. Concentration of PUN gradually increased after birth, reaching its highest concentration $(8.6 \mathrm{mmol} / \mathrm{L})$ at wk 3 . Milk yield was moderately (positively) correlated with fatty acids and BHB (Table 4) but weakly correlated with fatty acid-to-BHB ratio $(\mathrm{r}=0.15 ; P<0.001)$.

\section{Effects of Litter Size}

Increasing litter size increased $(P<0.05)$ milk yield and decreased $(P<0.05)$ BW and BCS at parturition. Primiparous does were less prolific than multiparous (1.6 vs. $1.8 \mathrm{kid} /$ goat; $P<0.001$ ). The effects of litter size on ante- and postpartum concentrations of glucose, fatty acids, BHB, and PUN in primiparous and multiparous does are presented in Table 5. For all metabolites, we found no significant difference in ante- or postpartum concentration between primiparous goats of different litter size. Multiparous does had consistently higher $(P$ $<0.05)$ fatty acids and BHB than primiparous does of equal litter size. Before parturition, multiparous goats carrying triplets had lower glucose $(-0.20 \mathrm{mmol} / \mathrm{L} ; P$ $<0.05)$ and higher fatty acid $(+0.20 \mathrm{mmol} / \mathrm{L} ; P<$ $0.05)$ and BHB $(+0.11 \mathrm{mmol} / \mathrm{L} ; P<0.05)$ concentrations than goats carrying singles. The effects of litter size disappeared after birth in both primiparous and multiparous goats.

\section{Effects of Parity Number}

Despite constant BW increase with increasing parity, the greatest milk yields were attained in third parity (Table 2). Parity number was positively correlated with levels of Milk-S, fatty acids, BHB, and PUN, and negatively correlated with glucose concentration (Table 4). Milk yield was positively correlated with BW in both multiparous and primiparous goats $(\mathrm{r}=0.13, P$ $=0.002 ;$ and $\mathrm{r}=0.40, P<0.001$, respectively). Milk-S correlated $(P<0.001)$ with fatty acid and BHB concentrations in both multiparous and primiparous goats, but values varied slightly between groups $(\mathrm{r}=0.27$ vs. 0.32 , and $\mathrm{r}=0.26$ vs. 0.21 , for fatty acids and BHB

Table 3. Weekly concentrations (mmol/L) of BHB, fatty acids, glucose, and plasma urea nitrogen (PUN) in commercial dairy goats during the transition period $(\mathrm{n}=940)^{1}$

\begin{tabular}{|c|c|c|c|c|c|c|c|c|c|}
\hline \multirow[b]{2}{*}{ Item } & \multicolumn{7}{|c|}{ Week relative to delivery } & \multirow[b]{2}{*}{$\mathrm{SED}^{2}$} & \multirow[b]{2}{*}{$P$-value } \\
\hline & -3 & -2 & -1 & 0 & 1 & 2 & 3 & & \\
\hline Milk-S ${ }^{3}$ & & & & & $2.25^{\mathrm{c}}$ & $2.48^{\mathrm{b}}$ & $2.54^{\mathrm{a}}$ & 0.028 & $<0.001$ \\
\hline Glucose & $3.29^{\mathrm{b}}$ & $3.23^{\mathrm{bc}}$ & $3.18^{\mathrm{bcd}}$ & $3.63^{\mathrm{a}}$ & $3.15^{\mathrm{bdc}}$ & $3.08^{\mathrm{d}}$ & $3.10^{\mathrm{cd}}$ & 0.061 & $<0.001$ \\
\hline Fatty acids & $0.36^{\mathrm{e}}$ & $0.43^{\mathrm{d}}$ & $0.44^{\mathrm{d}}$ & $0.55^{\mathrm{c}}$ & $0.67^{\mathrm{b}}$ & $0.83^{\mathrm{a}}$ & $0.89^{\mathrm{a}}$ & 0.034 & $<0.001$ \\
\hline $\mathrm{BHB}$ & $0.24^{\mathrm{c}}$ & $0.25^{\mathrm{c}}$ & $0.26^{\mathrm{c}}$ & $0.37^{\mathrm{b}}$ & $0.44^{\mathrm{a}}$ & $0.42^{\mathrm{a}}$ & $0.41^{\mathrm{a}}$ & 0.016 & $<0.001$ \\
\hline PUN & $6.91^{\mathrm{c}}$ & $6.97^{\mathrm{c}}$ & $7.26^{\mathrm{c}}$ & $7.02^{\mathrm{c}}$ & $8.01^{\mathrm{b}}$ & $8.43^{\mathrm{a}}$ & $8.63^{\mathrm{a}}$ & 0.169 & $<0.001$ \\
\hline
\end{tabular}

${ }^{\mathrm{a}-\mathrm{d}}$ Means within a row with different lowercase superscripts differ $(P<0.05)$.

${ }^{1}$ Values are back-transformed means. Number of does by factor combination is presented in Table 1.

${ }^{2} \mathrm{SED}=$ standard error of differences.

${ }^{3}$ Milk yield (L/d) 1 d before blood test. 
Table 4. Spearman rho correlations between parity number (PN), litter size (LS), milk yield 1 d before blood test (Milk-S, L/d), and concentrations (mmol/L) of BHB, fatty acids, glucose, and plasma urea nitrogen (PUN) in commercial dairy goats during the transition period $(\mathrm{n}=940)^{1}$

\begin{tabular}{|c|c|c|c|c|c|c|c|c|c|c|c|}
\hline \multirow[b]{2}{*}{ Item } & \multicolumn{5}{|c|}{ Antepartum } & \multicolumn{6}{|c|}{ Postpartum } \\
\hline & $\mathrm{PN}$ & LS & Glucose & Fatty acids & BHB & $\mathrm{PN}$ & LS & Glucose & Fatty acids & BHB & PUN \\
\hline Glucose & $-0.10^{* * *}$ & $-0.17^{* * *}$ & & & & $-0.16^{* * *}$ & $-0.04^{\dagger}$ & & & & \\
\hline $\begin{array}{l}\text { Fatty } \\
\text { acids }\end{array}$ & $0.12^{* * *}$ & $0.28^{* * *}$ & $-0.45^{* * *}$ & & & $0.16^{* * *}$ & $0.06^{* *}$ & $-0.51^{* * *}$ & & & \\
\hline $\mathrm{BHB}$ & $0.17^{* * *}$ & $0.25^{* * *}$ & $-0.23^{* * *}$ & $0.40^{* * *}$ & & $0.29 * * *$ & $0.12^{* * *}$ & $-0.29 * * *$ & $0.58^{* * *}$ & & \\
\hline
\end{tabular}

${ }^{1}$ Number of does by factor combination is presented in Table 1. Antepartum calculations between plasma metabolites included 2,745 simultaneous observations from d -24 to -3 relative to parturition; postpartum calculations between plasma metabolites and milk yield included 2,390 simultaneous observations from d 3 to 24 .

*** $P<0.001$; ** $P<0.01 ;{ }^{*} P<0.05 ; \dagger P<0.1$.

in primiparous vs. multiparous does, respectively). The average weekly concentrations of fatty acids, BHB, and PUN were consistently lower in first-parity goats than in goats of greater parities (Figure 1). Despite the numerical increase in fatty acid and BHB concentrations with increasing parity, no significant differences were detected for these parameters between parities 2,3 , and $4+$ (Figure 1).

\section{Effects of Level of Milk Production}

No significant interaction occurred between the level of milk production and parity $(2,3$, or $4+)$ on any of the variables analyzed (BW, BCS, milk yield). At parturition, LY goats were lighter $(-4.0 \mathrm{~kg} ; P<0.01)$ than HY goats (Table 2). However, HY and MY goats lost considerably more weight than LY goats from parturition to wk $6(-92,-85$, and $-27 \mathrm{~g} / \mathrm{d}$ for HY, MY and LY respectively; SED $=18.3 ; P<0.002)$.

The effects of the level of milk production on weekly concentrations of glucose, fatty acids, BHB, and PUN are presented in Figure 2. Concentrations of fatty acids, BHB, and PUN were greater $(P<0.01)$ post- than antepartum in all groups. Glucose concentration was lower $(P<0.001)$ post- than antepartum in both MY $(-7 \%)$ and $\mathrm{HY}$ goats $(-10 \%)$, with no difference in LY goats. Postpartum fatty acids, BHB, and PUN increased with increasing level of milk production, and HY goats had greater concentrations of fatty acids than LY $(+73 \%)$ and MY goats $(+16 \% ; P<0.001)$, greater BHB concentrations than LY $(+49 \%)$ and MY goats $(+16 \% ; P<0.001)$, and greater PUN concentrations

Table 5. Effects of litter size (LS) on antepartum (AP) and postpartum (PP) concentrations (mmol/L) of glucose, fatty acids, BHB, and plasma urea nitrogen (PUN) in primiparous (PRIM) and multiparous (MULT) goats ${ }^{1}$

\begin{tabular}{|c|c|c|c|c|c|c|c|c|c|}
\hline \multirow[b]{2}{*}{ Item } & \multirow[b]{2}{*}{ LS } & \multicolumn{2}{|c|}{$\mathrm{AP}$} & \multicolumn{2}{|c|}{$\mathrm{PP}$} & \multicolumn{2}{|c|}{$\mathrm{SED}^{2}$} & \multicolumn{2}{|c|}{$P$-value ${ }^{2}$} \\
\hline & & PRIM & MULT & PRIM & MULT & $\mathrm{AP}$ & $\mathrm{PP}$ & $\mathrm{AP}$ & $\mathrm{PP}$ \\
\hline Glucose & 3 & $3.5^{\mathrm{a}}$ & $3.1^{\mathrm{Cb}}$ & 3.2 & 3.0 & & & & \\
\hline \multirow{2}{*}{ Fatty acids } & 1 & $0.29^{\mathrm{b}}$ & $0.37^{\mathrm{Ba}}$ & $0.57^{\mathrm{b}}$ & $0.84^{\mathrm{a}}$ & 0.03 & 0.039 & 0.09 & 0.36 \\
\hline & 2 & $0.34^{\mathrm{b}}$ & $0.47^{\mathrm{ABa}}$ & $0.64^{\mathrm{b}}$ & $0.83^{\mathrm{a}}$ & & & & \\
\hline \multirow{2}{*}{ BHB } & 2 & $0.19^{\mathrm{b}}$ & $0.25^{\mathrm{Ba}}$ & $0.30^{\mathrm{b}}$ & $0.45^{\mathrm{a}}$ & & & & \\
\hline & 3 & $0.20^{\mathrm{b}}$ & $0.33^{\mathrm{Aa}}$ & $0.29^{\mathrm{b}}$ & $0.48^{\mathrm{a}}$ & & & & \\
\hline \multirow[t]{3}{*}{ PUN } & 1 & 6.9 & 7.1 & $7.8^{\mathrm{b}}$ & $8.7^{\mathrm{a}}$ & 0.02 & 0.02 & 0.98 & 0.80 \\
\hline & 2 & 6.8 & 6.9 & $7.6^{\mathrm{b}}$ & $8.6^{\mathrm{a}}$ & & & & \\
\hline & 3 & 6.9 & 7.1 & $7.2^{\mathrm{b}}$ & $8.1^{\mathrm{a}}$ & & & & \\
\hline
\end{tabular}

\footnotetext{
${ }^{\mathrm{a}, \mathrm{b}}$ Means antepartum or postpartum, within a row, with different lowercase superscripts differ $(P<0.05)$.

${ }^{\mathrm{A}-\mathrm{C}}$ Means within a column with different uppercase superscripts differ $(P<0.05)$.

${ }^{1}$ Values are back-transformed means. Antepartum calculations included samples from d -24 to -3 relative to parturition. Postpartum calculations included samples from d 3 to 24 . Number of goats tested is presented in Table 1.

${ }^{2}$ Joint effects of parity $\times$ LS. SED $=$ standard error of differences.
} 

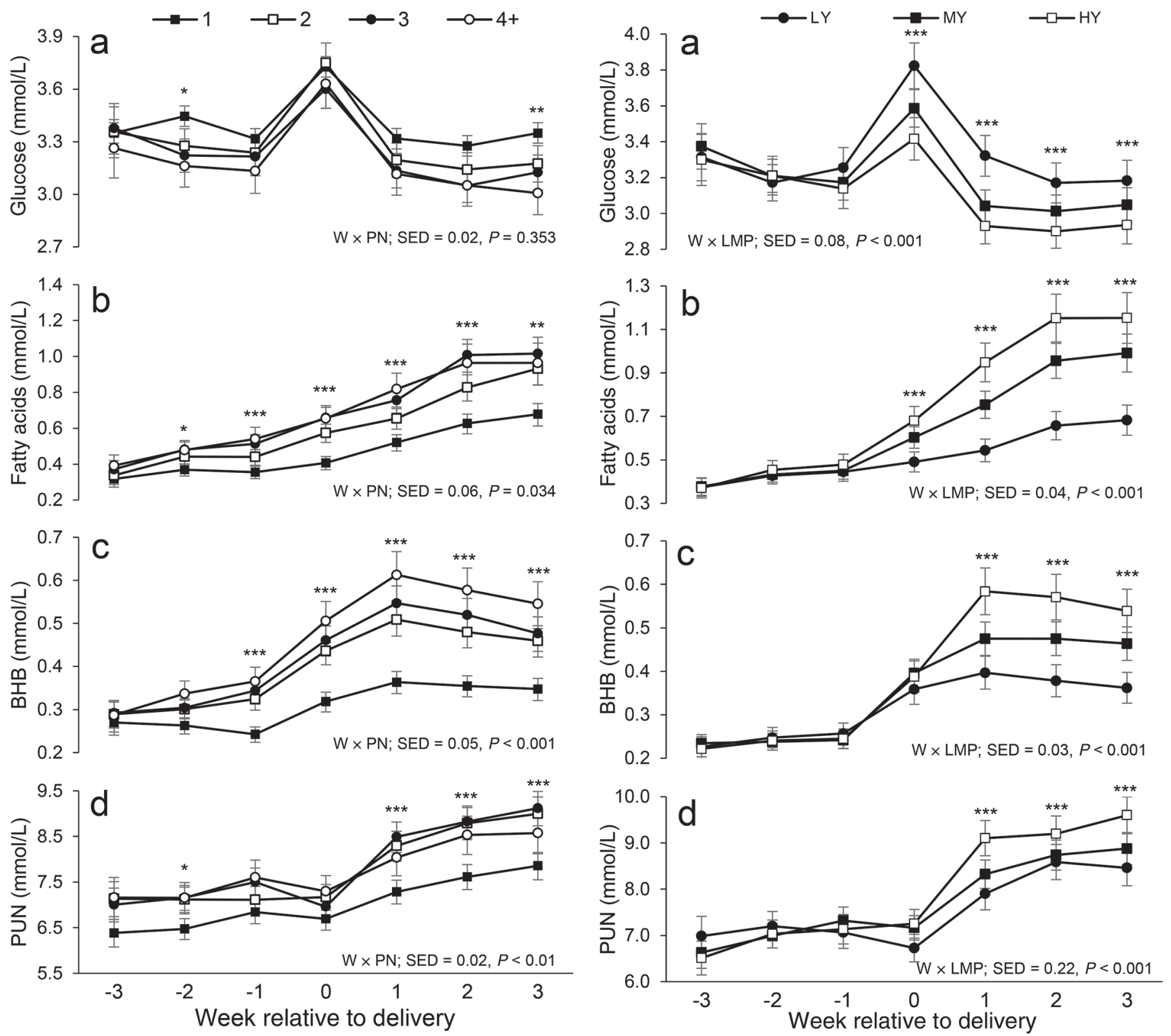

Figure 1. Effects of parity number $(\mathrm{PN})$ on weekly $(\mathrm{W})$ variations in concentrations of (a) glucose, (b) fatty acids, (c) BHB, and (d) plasma urea nitrogen (PUN) in periparturient dairy goats. Values are back-transformed means; error bars represent $95 \%$ CI. SED = standard error of differences. Weekly comparisons between groups; $* * * P<$ $0.001 ;{ }^{*} P<0.01 ;{ }^{*} P<0.05$. The number of goats tested each week is presented in Table 1 .

than LY $(+12 \%)$ and MY goats $(+8 \% ; P<0.01)$. The fatty acid-to-BHB ratio was greater post- than antepartum in HY (1.9 vs. 1.8 ; $\mathrm{SED}=0.01, P=0.023)$ and MY goats (1.9 vs. 1.7 ; $\mathrm{SED}=0.01, P<0.001)$, but we found no change in LY goats. The fatty acid-to-BHB ratio was greater in $\mathrm{HY}$ and MY goats compared with $\mathrm{LY}(1.9,1.8$, and 1.6; SED $=0.07, P<0.001)$ throughout the transition period.

Figure 2. Effects of level of milk production (LMP) on weekly (W) variations in concentrations of (a) glucose, (b) fatty acids, (c) BHB, and (d) plasma urea nitrogen (PUN) in low- (LY, $<2.4 \mathrm{~L} / \mathrm{d}$ ), medium(MY, 2.4 to $3.1 \mathrm{~L} / \mathrm{d}$ ), and high-yielding (HY, >3.1 L/d) multiparous dairy goats. Data for primiparous goats were not included in these calculations. Values are back-transformed means; error bars represent $95 \%$ CI. SED = standard error of differences. Weekly comparisons between groups; ${ }^{* * *} P<0.001 ;{ }^{*} P<0.05$. The number of goats tested each week is presented in Table 1.

\section{High- Versus Low-Yield Subset Group}

Mean $( \pm \mathrm{SD})$ milk yields of HY and LY goats were $3.7 \pm 0.31$ and $1.8 \pm 0.32 \mathrm{~L} / \mathrm{d}$, respectively. The HY and LY goats were homogeneous for litter size $(1.9 \pm$ $0.10 \mathrm{kid} /$ goat $)$ and $\mathrm{BCS}$ at parturition $(2.5 \pm 0.04)$, 
but $\mathrm{HY}$ goats were heavier and older than LY goats (respectively, 78 vs. $71 \mathrm{~kg}, \mathrm{SED}=0.07, P=0.014$; and 34 vs. $30 \mathrm{mo}$, SED $=1.4, P=0.003)$. The effects of milk production level on concentrations of hormones and metabolites are presented in Figure 3. We found no effect of milk production level on concentrations of hormones or metabolites in late pregnancy. Prolactin and insulin concentrations were lower $(P<0.01)$ postthan antepartum in both groups. Insulin was considerably lower in HY than in LY goats at wk 1 (2.0 vs. 6.8 $\mu \mathrm{U} / \mathrm{mL} ; P<0.001)$. We also observed a tendency for higher GH in HY than in LY goats at wk 3 (2.5 vs. $1.6 \mathrm{ng} / \mathrm{mL} ; P=0.075)$. After parturition, HY goats had lower glucose $(-11 \% ; P=0.001)$, higher fatty acid $(+52 \% ; P<0.001)$, and higher BHB concentrations $(+36 \% ; P<0.001)$ than LY goats. Postpartum insulin was negatively correlated with Milk-S $(\mathrm{r}=-0.31 ; P<$ $0.001)$, fatty acids $(\mathrm{r}=-0.67 ; P<0.001)$, and BHB ( $\mathrm{r}$ $=-0.42 ; P<0.001)$ only in LY goats, and postpartum ratios of glucose, fatty acids, and BHB to insulin were significantly higher in HY than in LY goats (Table 6).

\section{Effects of Elevated BHB and Fatty Acid Concentrations on Milk Yield and Culling Rates up to 30 DIM}

The odds ratio reported in Table 7 indicates the increase in likelihood of being removed from the milking herd before 30 DIM for every increase in the number of events of BHB and fatty acid concentrations above cut points. Each of the following positive events significantly increased the chances of early removal: antepartum BHB between 0.8 and $1.6=3$ times; antepartum BHB $>1.6=14.4$ times; antepartum fatty acids $>1.6=3.6$ times; and postpartum $\mathrm{BHB}>1.6=3.4$ times.

Milk yield increased $(P<0.001)$ with increasing fatty acids and was greater $(P=0.008)$ in goats with BHB between 0.8 and 1.6 than in goats with $\mathrm{BHB}$ below
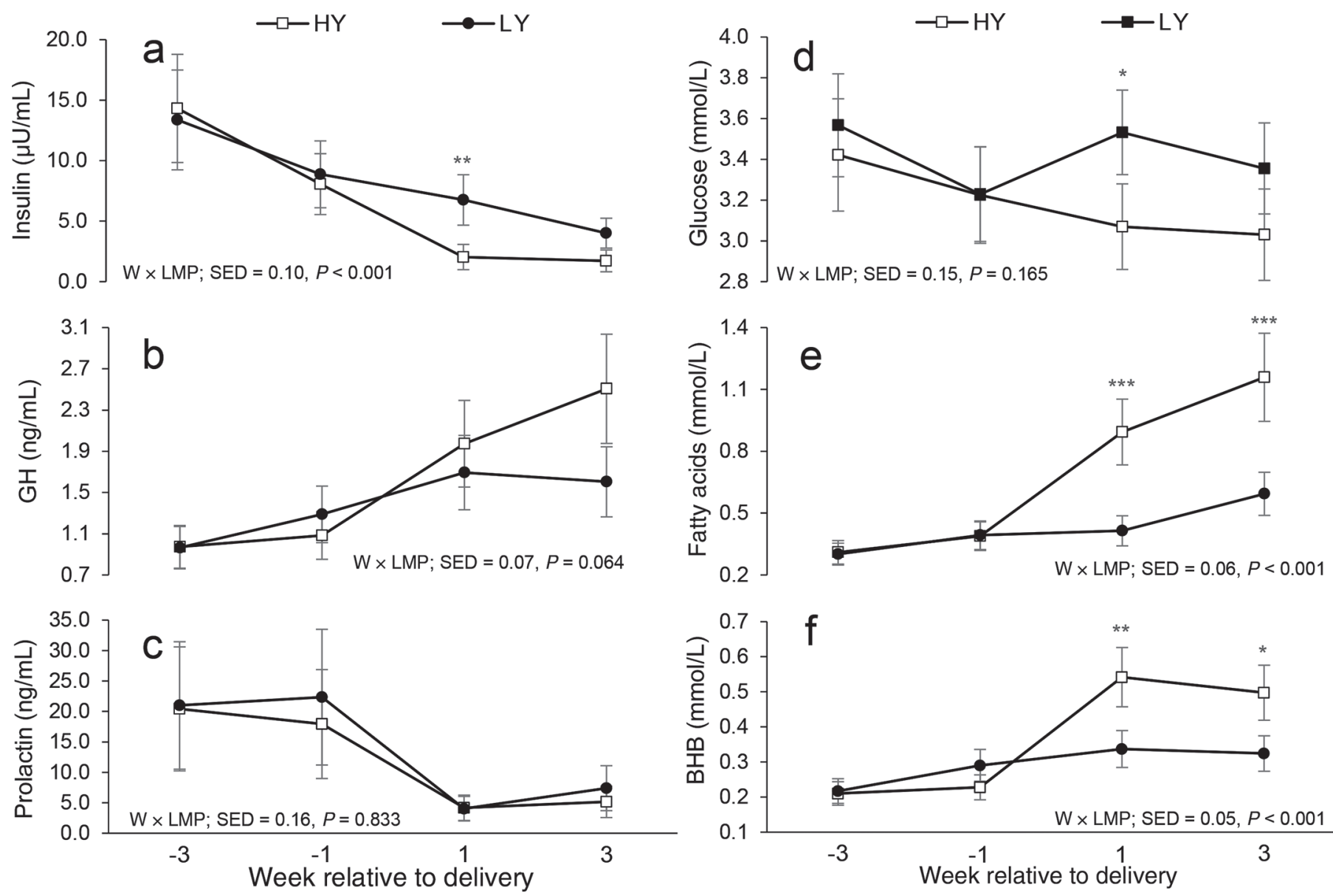

Figure 3. Effects of level of milk production (LMP) on weekly (W) variations in concentrations of (a) insulin, (b) growth hormone (GH), (c) prolactin, (d) glucose, (e) fatty acids, and (f) BHB, in high-yielding (HY, 3.7 L/d; $\mathrm{n}=40$ ) and low-yielding (LY, $1.8 \mathrm{~L} / \mathrm{d} ; \mathrm{n}=40)$ periparturient dairy goats. Values are back-transformed means; error bars represent $95 \%$ CI. SED $=$ standard error of differences. Weekly comparisons between groups; *** $P<0.001 ; * * P<0.01 ; * P<0.05$ 
Table 6. Ratios of glucose, fatty acid, and BHB concentrations $(\mathrm{mmol} / \mathrm{L})$ to insulin $(\mu \mathrm{U} / \mathrm{mL})$ in highyielding $(\mathrm{HY}, 3.7 \mathrm{~L} / \mathrm{d} ; \mathrm{n}=40)$ and low-yielding $(\mathrm{LY}, 1.8 \mathrm{~L} / \mathrm{d} ; \mathrm{n}=40)$ commercial dairy goats at 1 and $3 \mathrm{wk}$ postpartum $^{1}$

\begin{tabular}{clccc}
\hline Week & Item & Glucose/insulin & Fatty acids/insulin & BHB/insulin \\
\hline 1 & HY & 1.2 & 0.4 & 0.2 \\
& LY & 0.5 & 0.1 & 0.1 \\
& SED & 0.12 & 0.17 & 0.15 \\
3 & -value & 0.003 & $<0.001$ & $<0.001$ \\
& HY & 1.5 & 0.6 & 0.1 \\
& LY & 0.8 & 0.2 & 0.07 \\
& SED & 0.14 & $<.14$ & $<0.001$ \\
\hline
\end{tabular}

${ }^{1}$ Values are back-transformed means. SED $=$ standard error of differences.

$0.8 \mathrm{mmol} / \mathrm{L}$ (Figure 4). Correlations between Milk-S and fatty acid concentrations in goats with fatty acids $<0.8,0.8$ to 1.6 , and $>1.6 \mathrm{mmol} / \mathrm{L}$ were, respectively, $\mathrm{r}=0.27, P<0.001 ; \mathrm{r}=0.11, P=0.001 ;$ and $\mathrm{r}=$ $0.16, P=0.004$. Correlations between Milk-S and BHB concentration in goats with $\mathrm{BHB}<0.8,0.8$ to 1.6 , and $>1.6 \mathrm{mmol} / \mathrm{L}$ were, respectively, $\mathrm{r}=0.32, P<0.001 ; \mathrm{r}$ $=0.07, P=0.208 ;$ and $\mathrm{r}=-0.37, P=0.013$.

\section{DISCUSSION}

To the best of our knowledge, this is the first study exploring changes in endocrine and metabolic profiles of transition dairy goats from a large-scale farm where the herd is managed under intensive conditions. Importantly, this study used a considerably larger number of animals than any previous study that has investigated biomarkers of NEB in periparturient dairy goats. The large data set has enabled us to examine interrelationships between hormones and metabolite concentrations over time, to study their relationship with milk yield in early lactation, and to determine how these factors differed according to goats' parity and litter size.

\section{Metabolite Concentrations During the Transition Period}

The observed gradual decrease of glucose concentration as pregnancy progresses is typical for goats and ewes, for which late pregnancy is characterized by exponential fetal growth and progressive reduction in DMI due to physical compression of the rumen (Castagnino et al., 2015). The sudden rise in glucose concentration in the week of parturition (wk 0) is a normal response to parturition-induced endocrine changes that stimulate gluconeogenesis and lipolysis (Bell and Bauman, 1997; Hashizume et al., 1999).

In this experiment, fatty acid concentrations consistently increased from 1 wk before until 3 wk after parturition. Our results are consistent with reports in high-yielding cows (Wathes et al., 2007; McCarthy et al., 2015) but contrast with recent studies in postpartum Saanen goats of slightly higher milk production $(\sim 3 \mathrm{~L} / \mathrm{d})$, which reported a decrease $(21$ to $66 \%)$ in fatty acid concentrations from wk 0 to 2 (Magistrelli and Rosi, 2014; Radin et al., 2015). The reason for differences between studies is unclear, but it should be noted that, in contrast with the Magistrelli and Rosi (2014) study, where goats were kept in groups of 5 goat/pen, goats of the present experiment were managed (housed, fed, and milked) in a group of $\sim 600$ goats. Large group size might enhance food competition, potentially affecting individual DMI (Goetsch et al., 2010) but could also result in underfeeding of higher-yielding goats, thus aggravating NEB in this group (Sundrum, 2015). For example, because all goats were fed the same diet, to meet nutrient requirements, a $70-\mathrm{kg}$ goat producing up to $4.8 \mathrm{~L} / \mathrm{d}$ would need to consume $1.1 \mathrm{~kg}$ of DM/d

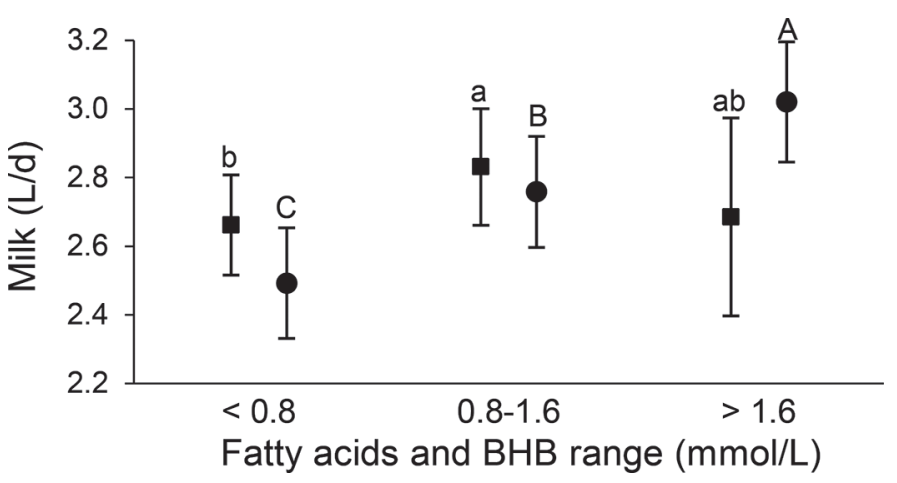

Figure 4. Average milk yield (L/d) according to fatty acid $(\mathbf{0})$ and BHB (ם) concentrations ( $\mathrm{mmol} / \mathrm{L})$. Data from 622 multiparous goats tested weekly from 3 to 30 DIM. Data for primiparous goats were not included in these calculations. The number of simultaneous observations (milk + plasma sample) for each concentration range $(<0.8,0.8$ to 1.6 , and $>1.6 \mathrm{mmol} / \mathrm{L}$ ) were $1,195,835$, and 387 for fatty acids (standard error of differences, SED $=0.05 ; P<0.001$ ), and 2,064, 308, and 45 for $\mathrm{BHB}(\mathrm{SED}=0.11 ; P=0.008)$. Error bars represent $95 \%$ CI. ${ }^{a, b}$ BHB means with different lowercase letters and ${ }^{\mathrm{A}-\mathrm{C}}$ fatty acid means with different uppercase letters differ $(P<0.05)$. 
Table 7. Association between number of events of BHB and fatty acids (mmol/L) at or above cut points and the odds of removal from the milking herd $\leq 30$ DIM $(\mathrm{n}=940)^{1}$

\begin{tabular}{|c|c|c|c|c|c|c|c|}
\hline Period & Cut point & Goats $^{2}(\%)$ & Coefficient & $\mathrm{SE}$ & Odds ratio & $95 \% \mathrm{CI}$ & $P$-value \\
\hline Antepartum $^{3}$ & $\mathrm{BHB}>1.6$ & 2 & 2.7 & 0.51 & 14.4 & $5.3-39.0$ & $<0.001$ \\
\hline \multirow[t]{3}{*}{ Postpartum $^{4}$} & BHB 0.8 to 1.6 & 29 & -0.2 & 0.39 & 0.8 & $0.4-1.7$ & 0.572 \\
\hline & $\mathrm{BHB}>1.6$ & 5 & 1.2 & 0.36 & 3.4 & $1.7-6.9$ & 0.001 \\
\hline & Fatty acids 0.8 to 1.6 & 70 & -0.3 & 0.29 & 0.7 & $0.4-1.3$ & 0.306 \\
\hline
\end{tabular}

${ }^{1}$ Number of does by factor combination is presented in Table 1.

${ }^{2}$ Percentage of goats with at least 1 positive event above cut point.

${ }^{3}$ From d -24 to -1 relative to delivery.

${ }^{4}$ From d 0 to 24 relative to delivery.

$(+61 \%)$ more than a goat of equal BW producing 1.6 L/d (National Research Council, 2007).

Despite the constant increase in fatty acid concentrations, BHB reached a plateau in the first week postpartum, remaining below hyperketonemic levels (BHB $\geq 0.8 \mathrm{mmol} / \mathrm{L}$; Marutsova and Binev, 2017) throughout the transition period. Although we did not measure changes in BHB production or utilization, it is known that BHB is more readily available for tissue uptake than fatty acids (Lean et al., 1992) and that BHB clearance is increased after parturition in dairy cows (Zarrin et al., 2017). Thus, the greater fatty acid-to-BHB ratio observed postpartum might be related to an enhanced BHB uptake capacity compared with fatty acids.

Moreover, postpartum BHB was lower than reported in dairy cows of similar postpartum fatty acid concentrations (McCarthy et al., 2015; Caré et al., 2018), which corroborates the findings of Toral et al. (2015), who reported higher BHB concentrations in cows than goats, even though fatty acids, glucose, and insulin concentrations were comparable between species. Additionally, dairy goats are reportedly less prone to develop pregnancy toxemia and lactational ketosis than are dairy ewes and cows, respectively (Pezzanite et al., 2009; Marutsova and Binev, 2017). The changes in plasma BHB concentration, in the present and other studies, suggest differences in ketone body metabolism between goats and cows, which in turn could be related to inherent interspecies differences in the intermediary metabolism of lipids (Delavaud et al., 2019) and mammary lipogenesis (Chilliard et al., 2014).

Furthermore, we observed a significant increase in PUN concentrations after parturition, which agrees with previous reports in dairy goats (Radin et al., 2015; Soares et al., 2018). In the current study, increases in milk yield were paralleled by increases in PUN concentration, and changes in PUN were positively associated with changes in BHB and fatty acid concentrations. Hence, changes in PUN concentration were most likely a reflection of enhanced catabolism of amino acids to support milk production during NEB. However, such changes in PUN concentration could also be related, at least in part, to changes in DMI (Van Saun, 2009) as well as to physiological and hormonal changes to nitrogen utilization efficiency as goats transition from pregnancy to lactation (Brun-Bellut, 1997).

\section{Litter Size}

The metabolic profiles of primiparous goats were not affected by litter size, which, together with the fact that multiparous goats had greater fatty acid and BHB concentrations than did primiparous goats of equal litter size, suggests that primiparous goats were partitioning nutrients toward body growth, most likely to the detriment of fetal development. Although we did not measure litter weight, this supposition is supported by the findings of González-García et al. (2014), who reported that, although the metabolic profiles of primiparous ewes were indifferent to litter size, their offspring were lighter and smaller than those born to multiparous dams.

In multiparous goats, increasing litter size increased lipid mobilization, as evidenced by higher fatty acid and BHB concentrations and lower BCS in goats delivering 2 or 3 kids compared with goats delivering 1 kid. Moreover, in dairy goats, multiple pregnancy is associated with reduced ingestion capacity (Soares et al., 2018) and higher colostrum yield (Lérias et al., 2014). Therefore, greater nutrient demands for colostrogenesis might have increased the metabolic burden on goats carrying 2 or 3 kids.

\section{Parity}

In multi- but not primiparous goats, BHB and fatty acid concentrations started to rise before onset of lactation. In goats, the phase of exponential mammary 
growth starts around 4 wk before delivery, and total udder volume at parturition (parenchyma + colostrum) increases with increasing parity number (Lérias et al., 2014). Thus, the higher antepartum concentrations of fatty acids and BHB in multiparous goats might reflect a higher nutrient requirement for colostrogenesis and mammary growth compared with primiparous goats.

Despite considerable variation in milk yield, BW, and BCS among multiparous goats, no significant difference in metabolic profile existed between goats in second or greater parity. On the other hand, primiparous goats had lower concentrations of fatty acids, BHB, and PUN, and lower milk yield than multiparous goats. Similar results have been reported in goats, sheep, and cows (Wathes et al., 2007; Magistrelli and Rosi, 2014; González-García et al., 2015). Collectively, previous and present results suggest that nutrient supply for body growth is prioritized over milk production in young ruminants. Additionally, we observed a stronger correlation between BW and milk yield for primiparous goats than for multiparous goats $(r=0.40$ and 0.13 , respectively), suggesting that in dairy goats, as in dairy cows (Wathes et al., 2007), initial body reserves are not only a key component of improved milk production in early lactation but might also be essential for optimum performance in primiparous goats.

\section{Level of Production}

Our results show no endocrine or metabolic differences between HY and LY goats in the antepartum period. On the other hand, similar to what has been reported in high-yielding cows (Bell and Bauman, 1997; Lucy et al., 2009), postpartum HY goats had lower insulin levels and tended to have greater $\mathrm{GH}$ concentration than LY goats. Additionally, the ratios of glucose, fatty acids, and BHB to insulin were considerably higher in HY compared with LY goats, indicating a homeorhetic shift in metabolism toward catabolic pathways, which might explain the increased mobilization of body tissues in support of enhanced milk production among this group.

Growth hormone favors nutrient supply to the mammary gland by stimulating gluconeogenesis, lipolysis, and blood flow, but also by antagonizing insulin action in several tissues (Bell and Bauman, 1997). However, postpartum GH was not significantly associated with either Milk-S, hormones, or metabolites in our study. Secretion of GH is pulsatile in goats, and both the amplitude and frequency of GH pulses may vary from goat to goat and according to environmental and physiological conditions (Jin et al., 2012). Therefore, because we used single GH measurements, our results might not be an accurate representation of individual and groupaverage GH baseline levels.

\section{Effects of Elevated BHB and Fatty Acid Concentrations on Milk Yield and Culling Rates up to 30 DIM}

In goats, plasma $\mathrm{BHB} \geq 0.8 \mathrm{mmol} / \mathrm{L}$ is associated with increased risk of subclinical ketosis, and BHB $>1.6$ $\mathrm{mmol} / \mathrm{L}$ is associated with the clinical presentation of ketosis (Albay et al., 2014; Doré et al., 2015; Marutsova and Binev, 2017). In our study, almost $30 \%$ of goats had at least 1 event of BHB $\geq 0.8 \mathrm{mmol} / \mathrm{L}$ postpartum, and the mean concentration of fatty acids was consistently above cattle thresholds $(\geq 0.7 \mathrm{mmol} / \mathrm{L})$, but only 21 goats $(2 \%)$ were removed from the milking herd before 30 DIM. Because culling reasons were, in large part, related to animal health (e.g., low milk yield, illness, injury, or death), we anticipated a link between culling rates and elevated BHB and fatty acid concentrations. This hypothesis was further supported by the increased risk of culling in pregnant goats with $\mathrm{BHB} \geq 0.8 \mathrm{mmol} / \mathrm{L}$ or fatty acids $>1.6 \mathrm{mmol} / \mathrm{L}$, and in postpartum goats with fatty acids $>1.6 \mathrm{mmol} / \mathrm{L}$. Interestingly, though, goats with fatty acids $>1.6 \mathrm{mmol} / \mathrm{L}$ had the highest milk yield, and milk yield decreased only slightly in goats with $\mathrm{BHB}>1.6 \mathrm{mmol} / \mathrm{L}$.

The positive association between postpartum fatty acids and milk yield appears contrary to previous research in dairy cows (Overton et al., 2017) and suggests that goats might be more resilient to elevated fatty acid concentrations than cows are. However, it is important to note that metabolic profiles may vary from farm to farm, depending on species, genotype, average milk yield, diet composition, and farm management system, as well as other factors (Van Saun, 2009; Overton et al., 2017).

\section{Industry Implications}

A more thorough understanding of endocrine and metabolic regulation of body tissue mobilization would contribute to the development of feeding and management practices for improved milk production in dairy goats. Because this study was carried out on a commercial farm, it provides a more realistic estimation of the metabolic burden experienced by periparturient dairy goats managed under intensive conditions. Based on the present results, it is plausible to conclude that the nutritional deficit grew with, in order of importance, increasing milk yield, parity, and litter size.

Manipulating the energy density of the diet could help to narrow the gap between energy demand and 
supply, thereby reducing lipid mobilization in the transition period (Hayirli and Grummer, 2004; Celi et al., 2008). Recent studies have demonstrated that grouping cows based on simultaneous nutritional needs can considerably improve the profitability of dairy farms by increasing milk yield, decreasing risks of metabolic diseases, and reducing nutrient waste and feed costs (Kalantari et al., 2016). It is only logical to suppose that such practices would yield similar results if adopted by goat dairy farmers.

Nonetheless, nutritional grouping may not be practical in many goat dairy systems, because managing multiple TMR groups requires greater management complexity, which, in turn, increases labor costs (Kalantari et al., 2016; Goetsch, 2019). In such cases, varying the amount of concentrate fed in the milking parlor could be an effective way to improve the energy balance and overall performance of dairy goat herds. Moreover, recent advances in the feeding practices and nutrition of dairy goats have shown considerable opportunity for improving the metabolic health of fresh goats and for minimizing production costs though dietary inclusion of alternative feedstuffs (e.g., fats and oils, by-products, former foodstuffs; Goetsch, 2019).

\section{CONCLUSIONS}

The presented data indicate that increased milk yield has the most significant influence on the magnitude of body tissue mobilization and suggests that the differing endocrine background of high-yielding goats may favor the partitioning of nutrients into milk. Furthermore, pregnancy and lactation were less able to elicit lipid mobilization in primiparous compared with multiparous goats. On the other hand, associations between milk, fatty acids, and BW indicate that BW at birth is of greater importance for improved milk production in primiparous than in multiparous goats. Moreover, goats in late pregnancy were more susceptible to metabolic complications due to elevated BHB and fatty acid concentrations than goats in early lactation. Nevertheless, fatty acid thresholds established for dairy cows were not predictive of dairy goat performance. Further investigation into differences in insulin resistance between high- and low-yielding goats in early lactation, the economic effects of nutritional grouping, and the determination of critical BHB and fatty acid thresholds specific to dairy goats is warranted.

\section{ACKNOWLEDGMENTS}

Fernanda Zamuner received a $\mathrm{PhD}$ scholarship financed by the Australian Government Research Training Program (Melbourne, VIC, Australia). The authors gratefully acknowledge the personnel of Meredith Dairy Ltd. (Meredith, VIC, Australia) for their assistance throughout this study. The authors declare that there were no conflicts of interest during the entire process of this study.

\section{REFERENCES}

Albay, M. K., M. Ç. Karakurum, Ş. Şahinduran, K. Sezer, R. Yıldız, and T. Büyükoğlu. 2014. Selected serum biochemical parameters and acute phase protein levels in a herd of Saanen goats showing signs of pregnancy toxaemia. Vet. Med. (Czech.) 59:336-342. https://doi.org/10.17221/7620-VETMED.

Bell, A. W., and D. E. Bauman. 1997. Adaptations of glucose metabolism during pregnancy and lactation. J. Mammary Gland Biol. Neoplasia 2:265-278. https://doi.org/10.1023/A:1026336505343.

Brun-Bellut, J. 1997. Urea recycling in the rumen of dairy goats: Effects of physiological stage and composition of intake. Small Rumin. Res. 23:83-90. https://doi.org/10.1016/S0921-4488(96)00910 $-8$

Cappai, M. G., A. Liesegang, C. Dimauro, F. Mossa, and W. Pinna. 2019. Circulating electrolytes in the bloodstream of transition Sarda goats make the difference in body fluid distribution between single vs. twin gestation. Res. Vet. Sci. 123:84-90. https://doi.org/ 10.1016/j.rvsc.2018.12.016.

Caré, S., E. Trevisi, A. Minuti, A. Ferrari, J. J. Loor, and L. Calamari. 2018. Plasma fructosamine during the transition period and its relationship with energy metabolism and inflammation biomarkers in dairy cows. Livest. Sci. 216:138-147. https://doi.org/10.1016/j .livsci.2018.08.003.

Castagnino, D. S., C. J. Härter, A. R. Rivera, L. D. Lima, H. G. O. Silva, B. Biagioli, K. T. Resende, and I. A. M. A. Teixeira. 2015. Changes in maternal body composition and metabolism of dairy goats during pregnancy. Rev. Bras. Zootec. 44:92-102. https://doi .org/10.1590/S1806-92902015000300003.

Celi, P., A. Di Trana, and S. Claps. 2008. Effects of perinatal nutrition on lactational performance, metabolic and hormonal profiles of dairy goats and respective kids. Small Rumin. Res. 79:129-136. https://doi.org/10.1016/j.smallrumres.2008.07.010.

Chilliard, Y., P. G. Toral, K. J. Shingfield, J. Rouel, C. Leroux, and L. Bernard. 2014. Effects of diet and physiological factors on milk fat synthesis, milk fat composition and lipolysis in the goat: A short review. Small Rumin. Res. 122:31-37. https://doi.org/10.1016/j .smallrumres.2014.07.014.

Delavaud, C., H. Fougère, Y. Chilliard, and L. Bernard. 2019. The dietary addition of fish oil or sunflower oil plus starch differently modulates the lipid classes in plasma of lactating cows and goats. Eur. J. Lipid Sci. Technol. 121:1900075. https://doi.org/10.1002/ ejlt.201900075.

Doré, V., J. Dubuc, A. Bélanger, and S. Buczinski. 2015. Definition of prepartum hyperketonemia in dairy goats. J. Dairy Sci. 98:45354543. https://doi.org/10.3168/jds.2014-9172.

Goetsch, A. 2019. Recent research of feeding practices and the nutrition of lactating dairy goats. J. Appl. Anim. Res. 47:103-114. https://doi.org/10.1080/09712119.2019.1580585.

Goetsch, A. L., T. A. Gipson, A. R. Askar, and R. Puchala. 2010. Invited review: Feeding behavior of goats. J. Anim. Sci. 88:361-373. https://doi.org/10.2527/jas.2009-2332.

González-García, E., V. Gozzo de Figuereido, D. Foulquie, E. Jousserand, P. Autran, S. Camous, A. Tesnière, F. Bocquier, and M. Jouven. 2014. Circannual body reserve dynamics and metabolic profile changes in Romane ewes grazing on rangelands. Domest. Anim. Endocrinol. 46:37-48. https://doi.org/10.1016/j.domaniend .2013.10.002.

González-García, E., A. Tesnière, S. Camous, F. Bocquier, F. Barillet, and P. Hassoun. 2015. The effects of parity, litter size, physiological state, and milking frequency on the metabolic profile of Lacaune dairy ewes. Domest. Anim. Endocrinol. 50:32-44. https:/ /doi.org/10.1016/j.domaniend.2014.07.001. 
Hashizume, T., Y. Takahashi, M. Numata, K. Sasaki, K. Ueno, K. Ohtsuki, and A. Ishii. 1999. Plasma profiles of growth hormone, prolactin and insulin-like growth factor-I during gestation, lactation and the neonatal period in goats. J. Reprod. Dev. 45:273-281. https://doi.org/10.1262/jrd.45.273.

Hayirli, A., and R. Grummer. 2004. Factors affecting dry matter intake prepartum in relationship to etiology of peripartum lipidrelated metabolic disorders: A review. Can. J. Anim. Sci. 84:337347. https://doi.org/10.4141/A03-122.

Herdt, T. H. 2000. Ruminant adaptation to negative energy balance: Influences on the etiology of ketosis and fatty liver. Vet. Clin. North Am. Food Anim. Pract. 16:215-230. https://doi.org/10 .1016/S0749-0720(15)30102-X.

Jin, J., T. Yaegashi, K. Sawai, and T. Hashizume. 2012. Effects of photoperiod on the secretion of growth hormone in female goats. Anim. Sci. J. 83:610-616. https://doi.org/10.1111/j.1740-0929 .2011.00998.x.

Johnson, M. M., and J. P. Peters. 1993. An improved method to quantify nonesterified fatty acids in bovine plasma. J. Anim. Sci. 71:753-756. https://doi.org/10.2527/1993.713753x.

Kalantari, A. S., L. E. Armentano, R. D. Shaver, and V. E. Cabrera. 2016. Economic impact of nutritional grouping in dairy herds. J. Dairy Sci. 99:1672-1692. https://doi.org/10.3168/jds.2015-9810.

Lean, I. J., M. L. Bruss, R. L. Baldwin, and H. F. Troutt. 1992. Bovine ketosis: A review. II. Biochemestry and prevention. Vet. Bull. 62:1-14.

Lérias, J. R., L. E. Hernández-Castellano, A. Suárez-Trujillo, N. Castro, A. Pourlis, and A. M. Almeida. 2014. The mammary gland in small ruminants: Major morphological and functional events underlying milk production-A review. J. Dairy Res. 81:304-318. https://doi.org/10.1017/S0022029914000235.

Lucy, M. C., G. A. Verkerk, B. E. Whyte, K. A. Macdonald, L. Burton, R. T. Cursons, J. R. Roche, and C. W. Holmes. 2009. Somatotropic axis components and nutrient partitioning in genetically diverse dairy cows managed under different feed allowances in a pasture system. J. Dairy Sci. 92:526-539. https://doi.org/10.3168/ jds.2008-1421.

Magistrelli, D., and F. Rosi. 2014. Trend analysis of plasma insulin level around parturition in relation to parity in Saanen goats. J. Anim. Sci. 92:2440-2446. https://doi.org/10.2527/jas.2013-6993.

Marutsova, V., and R. Binev. 2017. Body condition score, nonesterified fatty acids and beta-hydroxybutyrate concentrations in goats with subclinical ketosis. Agric. Sci. Technol. 9:282-285. https://doi .org/10.15547/ast.2017.04.053.

Matthews, J. G. 2016. The periparturient goat. Pages 41-60 in Diseases of the Goat. 4th ed. John Wiley and Sons Ltd., Chichester, UK.

McCarthy, M. M., S. Mann, D. V. Nydam, T. R. Overton, and J. A. A. McArt. 2015. Concentrations of nonesterified fatty acids and $\beta$-hydroxybutyrate in dairy cows are not well correlated during the transition period. J. Dairy Sci. 98:6284-6290. https://doi.org/10 $.3168 /$ jds.2015-9446.

National Research Council. 2007. Nutrient Requirements of Small Ruminants: Sheep, Goats, Cervids, and New World Camelids. Natl. Acad. Press., Washington, DC.

Overton, T. R., J. A. A. McArt, and D. V. Nydam. 2017. A 100year review: Metabolic health indicators and management of dairy cattle. J. Dairy Sci. 100:10398-10417. https://doi.org/10.3168/jds .2017-13054.

Pezzanite, L., D. M. Neary, T. Hutchens, and D. P. Scharko. 2009. Common diseases and health problems in sheep and goats. Knowledge to Go. Purdue Extension, West Lafayette, IN. Accessed Jun. 16, 2019. https://www.extension.purdue.edu/extmedia/as/as-595 -commondiseases.pdf.
Radin, L., M. Šimpraga, S. Vince, A. Kostelić, and S. Milinković-Tur. 2015. Metabolic and oxidative status of Saanen goats of different parity during the peripartum period. J. Dairy Res. 82:426-433. https://doi.org/10.1017/S0022029915000552.

Soares, G., R. Souto, J. Cajueiro, J. Afonso, R. Rego, A. Macêdo, P. Soares, and C. Mendonça. 2018. Adaptive changes in blood biochemical profile of dairy goats during the period of transition. Rev. Med. Vet. 169:65-75.

Stelletta, C., M. Gianesella, and M. Morgante. 2008. Metabolic and nutritional diseases. Pages 263-288 In Dairy Goats Feeding and Nutrition, Vol. 1. A. Cannas and G. Pulina, ed. CABI, Bologna, Italy.

Sundrum, A. 2015. Metabolic disorders in the transition period indicate that the dairy cows' ability to adapt is overstressed. Animals (Basel) 5:978-1020. https://doi.org/10.3390/ani5040395.

Thomas, G. B., J. E. Mercer, T. Karalis, A. Rao, J. T. Cummins, and I. J. Clarke. 1990. Effect of restricted feeding on the concentrations of growth hormone $(\mathrm{GH})$, gonadotropins, and prolactin (PRL) in plasma, and on the amounts of messenger ribonucleic acid for GH, gonadotropin subunits, and PRL in the pituitary glands of adult ovariectomized ewes. Endocrinology 126:1361-1367. https://doi .org/10.1210/endo-126-3-1361.

Toral, P. G., Y. Chilliard, J. Rouel, H. Leskinen, K. J. Shingfield, and L. Bernard. 2015. Comparison of the nutritional regulation of milk fat secretion and composition in cows and goats. J. Dairy Sci. 98:7277-7297. https://doi.org/10.3168/jds.2015-9649.

Van Saun, R. 2009. Metabolic profiling. Pages 153-162 in Current Veterinary Therapy: Food Animal Practice, 5th ed. D. E. Anderson and D. M. Rings, ed. W. B. Saunders, Edinburgh, UK.

Villaquiran, M., T. Gipson, R. Merkel, A. Goetsch, and T. Sahlu. 2004. Body condition scores in goats. American Institute for Goat Research, Langston University, Langston, OK. Accessed Mar. 18, 2016. http://www.luresext.edu/sites/default/files/BCS_factsheet .pdf.

Wankhade, P. R., A. Manimaran, A. Kumaresan, S. Jeyakumar, K. Ramesha, V. Sejian, D. Rajendran, and M. R. Varghese. 2017. Metabolic and immunological changes in transition dairy cows: A review. Vet. World 10:1367-1377. https://doi.org/10.14202/ vetworld.2017.1367-1377.

Wathes, D. C., Z. Cheng, N. Bourne, V. J. Taylor, M. P. Coffey, and S. Brotherstone. 2007. Differences between primiparous and multiparous dairy cows in the inter-relationships between metabolic traits, milk yield and body condition score in the periparturient period. Domest. Anim. Endocrinol. 33:203-225. https://doi.org/10.1016/j .domaniend.2006.05.004.

Zalcman, E., and B. Cowled. 2018. Farmer survey to assess the size of the Australian dairy goat industry. Aust. Vet. J. 96:341-345. https://doi.org/10.1111/avj.12734.

Zamuner, F., K. DiGiacomo, A. Cameron, and B. Leury. 2020. Effects of month of kidding, parity number, and litter size on milk yield of commercial dairy goats in Australia. J. Dairy Sci. 103:954-964. https://doi.org/10.3168/jds.2019-17051.

Zarrin, M., L. Grossen-Rösti, R. Bruckmaier, and J. J. Gross. 2017. Elevation of blood $\beta$-hydroxybutyrate concentration affects glucose metabolism in dairy cows before and after parturition. J. Dairy Sci. 100:2323-2333. https://doi.org/10.3168/jds.2016-11714.

\section{ORCIDS}

F. Zamuner (ㄴ) https://orcid.org/0000-0002-9409-8779

K. DiGiacomo @ https://orcid.org/0000-0002-6590-3513

B. J. Leury @ https://orcid.org/0000-0001-9173-2730 